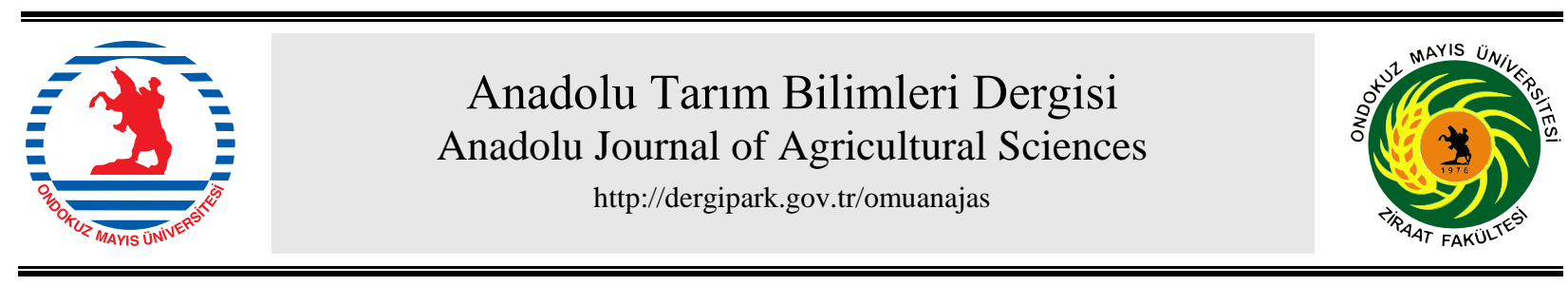

\section{Araştırma/Research}

Anadolu Tarım Bilim. Derg./Anadolu J Agr Sci, 34 (2019)

ISSN: 1308-8750 (Print) 1308-8769 (Online) doi: 10.7161/omuanajas.408742

\title{
Çiftçilerin kooperatifçilik eğitimi alma isteğini etkileyen faktörler: Çanakkale ili örneği
}

\author{
Bengü Everest*, Ayşe Gül Yavaş, Ebru Tatar, Fatma Çakar, İlker Acar \\ Çanakkale Onsekiz Mart Üniversitesi Ziraat Fakültesi Tarım Ekonomisi Bölümü, Çanakkale \\ "Sorumlu yazar/corresponding author: beverest@comu.edu.tr
}

Geliş/Received 22/03/2018 Kabul/Accepted 25/01/2019

\begin{abstract}
ÖZET
Gün geçtikçe önemi giderek daha çok anlaşılan kooperatifçilik tüm sektörlerde olduğu gibi tarım sektöründe de sorunlara çözüm önerisi olarak konuşulmaktadır. Kooperatifçilik üzerine yapılan çalışmalarda ise kooperatiflerin yeteri kadar başarılı olmaması sorun olarak görülmektedir. Yapılan çalışmalar kooperatifçilik bilincinin geliştirilmesi gerektiğini ortaya koymaktadır. Dolayısıyla bu çalışmada kırsal alanda yaşayanların kooperatifçilik eğitimi taleplerinin ortaya konması amaçlanmıştır. $\mathrm{Bu}$ amaçla Çanakkale ilindeki tüm ilçelerden en fazla ortağı olan tarımsal kalkınma kooperatifleri gayeli olarak seçilmiş ve bu kooperatiflere ortak 93 çiftçi ile görüşülmüştür. Çiftçilerin kooperatifçilik eğitimi alma isteğine etkili faktörler Lojistik Regresyon analizi yardımıyla belirlenmiştir. Araştırma bulgularına göre kooperatif ortaklarının \%61'i kooperatifçilik konusunda eğitim almak istemektedirler. Kooperatifçilik konusunda eğitim alma isteği üzerinde çiftçilerin yaş seviyeleri negatif, internet kullanma durumları pozitif ve tarımsal fuarları ziyaret etme durumları negatif yönde etkili bulunmuştur. Ortakların eğitimini almak istedikleri ilk konu "başarılı kooperatifleri yerinde görüp öğrenme"dir.
\end{abstract}

Factors affecting the desire of farmers for cooperative training: Çanakkale province example

\section{ABSTRACT}

As the day progresses more and more, the importance of solving cooperative problems in agricultural sectors has been talked about and understood as in all other sectors. In cooperative study, failure of cooperatives is discussed as a problem. Studies show that awareness of cooperatives should be improved. Therefore, in this study, it was aimed to determine the cooperative education demands in the rural areas. For this purpose, major agricultural development cooperative partners of all the provinces in Çanakkale province were selected. In the survey 93 farmers were selected from these cooperatives. Factors influencing the desire of farmers to receive cooperative training were determined with the help of Logistic Regression Analysis. According to research findings, 61\% of cooperative partners want to receive training on cooperatives. On the desire to receive training on cooperatives; the farmers' age levels were negative, the use of internet was positive, and the visits to agricultural fairs were found to be negative. The first thing that partners want to learn is "to see and learn successful co-operatives".

Anahtar Sözcükler: Eğitim talebi Lojistik regresyon Kooperatifçilik Çanakkale

\section{Giriş}

İnsanoğlu doğası gereği yalnız yaşayamaz ve birbirine yardım etmeye muhtaçtır. Nitekim modern anlamda kurulan ilk kooperatif de insanların daha iyi koşullarda yaşama isteği neticesinde 1844 yılında İngiltere'de kurulmuştur (Mülayim, 2010). 170 y1l önce 28 dokuma işçisinin başlattığı bu hareket, günümüzde tüm kıtalarda ve tüm ülkelerde yaygınlaşmıştır (Everest, 2015).
Bugün dünyada 1 milyar civarında kooperatif ortaklığı olduğu düşünülmektedir (Ticaret Bakanlığı, 2018a). Besinsel gereksinmeleri karşılama, tarım dış1 sektörlere hammadde üretme, sağlıklı işgücü sağlama, ruhsal denge unsuru olma ve kalkınmanın finansmanını sağlama gibi fonksiyonları olan tarım sektörünün (Dinler, 2008) geniş bir örgütlenme yelpazesi bulunmaktadır. Türkiye'de tarım sektörünün örgütlenmesi kooperatifler, üretici birlikleri, sslah amaçlı yetiştirici birlikleri, ziraat odaları, sulama 
birlikleri, çiftçi dernekleri ve tarımsal vakıflardan oluşmaktadır (Yercan, 2007). Tarım işletmeleri, çok farklılık gösteren ihtiyaçlarını çok sayıda örgüte üye olarak karşılamak zorunda kalmaktadır. (Topuz ve ark, 2017). $\mathrm{Bu}$ örgütlerden kooperatiflerin tarım, hayvanc1lı, ormanc1lı, çay, sulama, su ürünleri, pancar ekicileri, tarım kredi, tarım satış gibi türleri bulunmaktadır.

Kooperatiflerin gelişmiş ülkelerde ülke ekonomilerine sağladıkları katkılar göz ardı edilemez. Uluslararas1 Kooperatifler Birliği (ICA) 2017 y1l verilerine göre 56 ülkede, 2032 kooperatifin toplam satış işlemleri 2.164 milyar \$'dır (ICA, 2019).

Türkiye'de 12.619 tarımsal amaçlı kooperatif olup bu kooperatiflere ortak çiftti sayısı 4.327.759 kişidir (TRGM, 2018). Türkiye'de örgütlenme ile ilgili sorunlar nicelik değil nitelik olarak karşımıza çıkmaktadır (Tan ve Karaönder, 2013). Kooperatifler sayıca fazla ancak özellikle ürün pazarlamada yeteri kadar etkili değillerdir.

Oysa çiftçi örgütlerinden biri olan kooperatifler gelişmiş ülkelerde özellikle tarımsal ürünleri pazarlanmasında önemli rol oynamaktadırlar (Semerci, 2015). İlave olarak bir kooperatifi gerçek bir kooperatif yapan, onun kooperatif adını taşıması değil, gerçek bir kooperatifte uygulanmasi gereken ilkeleri uygulayıp uygulamadığıdır (Mülayim, 2010). Ayrıca başarılı kooperatifçilik için kooperatif yöneticileri geleneksel kooperatif ilkelerine bağlı olmalı (Adrian ve Green, 2001), kooperatifler diğer kooperatiflerle işbirliği içerisinde olmalı (Aydoğan ve ark., 2016), temel kooperatif değerleri, kooperatif mevzuatları, tipik kooperatif yönetim şekli, kooperatiflerin avantajları göz önüne alınmalı (Prakash, 2003), kooperatif sosyal performansinin algilanmasinda kooperatif prensiplerinin algısı da ölçülmeli (Karthikeyan, 2013), kooperatif yöneticilerine ve ortaklarına kooperatif ilkeleri ile ilgili eğitim verilmeli (Oladejo, 2013), kooperatif operasyonlarında başarı için kooperatif yönetimine katılım sağlanmalı (Gray ve Kraenzle, 1998), kooperatife olan toplam bağımlılık artıılmalı (Loursen ve ark., 2008), kooperatif ortaklarının motivasyonu yüksek olmalı (Xiang ve Sumelius, 2010), ortaklar kooperatife güvenmeli (Didier ve ark., 2012), ortaklar kooperatife ortak olmaya devam etme niyetinde olmal 1 (Espallardo ve ark., 2012), kooperatif ortaklarında liderlik algısı olmalıdır (Zakic ve ark., 2013) ve ayrıca kadın üreticilerin de kooperatiflere katılması sağlanmalıdır (Hazneci ve ark., 2012). Bütün bu tespitler ise doğrudan kooperatifçilik bilincine bağlıdır.

Türkiye'de kooperatifçilik bilincinin düşük düzeyde olması eğitimle doğrudan alakalı bir konudur (Güreşçi ve Gönç, 2017). Şekil 1'de görüldüğü gibi kooperatifler ekonomik, sosyal ve insani boyutları ile ele alındığında birçok bilim dalı ile ilişkilidir (Everest ve Tan, 2016).

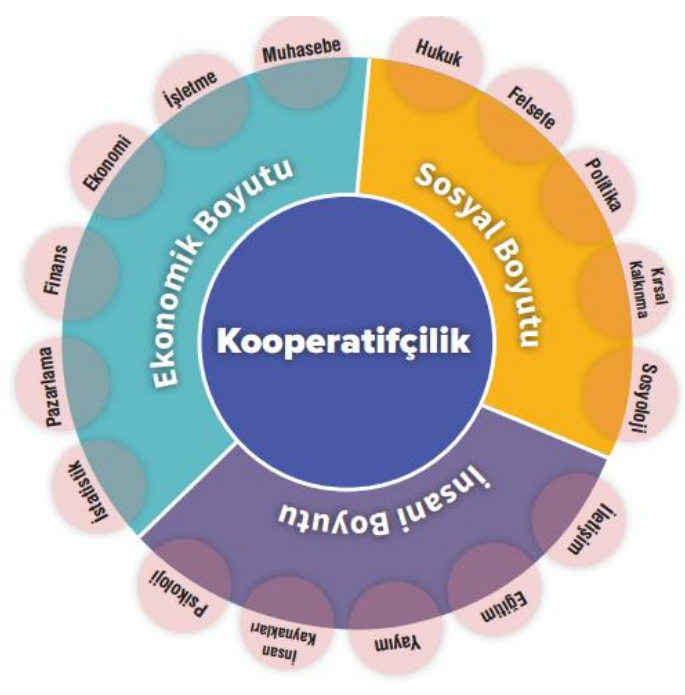

Şekil 1. Kooperatifçiliğin diğer bilim dalları ile ilişkisi

Başarılı kooperatifçilik eğitimleri için bu husus gözönünde tutularak eğitim programları oluşturulmalıdır. Kooperatif eğitimleri kooperatif ortağ olanlar için kooperatif faaliyetlerini geliştirmek ve ortak olmayanlar için kooperatifçiliği yaygınlaştırmak amacıyla yapılmalıdır. Kooperatifçiliğin prensiplerinin yanı sıra Grafik 1'de belirtilen bilim dalları ile ilgili temel bilgilerin de kooperatifçilik eğitimlerine dâhil edilmesi kooperatif sektörüne olumlu katk1 sağlayacaktır.

Türkiye Kooperatifçilik Stratejisi ve Eylem Planında da eğitim, bilinçlendirme ve araştırma faaliyetlerindeki yetersizlikler Türkiye'de kooperatifçiliğin mevcut sorunlarından biri olarak belirtilmiştir (Ticaret Bakanlı̆̆1, 2018b).

Kooperatifçilik eğitiminin temel amacı, halkın toplumsal ve ekonomik sorunlarının farkına varması, bunların çözümünde örgütlenme biçimi olarak kooperatiften yararlanmaya yöneltilmesi, kooperatifin kurulması, geliştirilmesi, işletilmesi için bilgi, beceri ve davranışlarında değişimlerin gerçekleştirilmesidir (Geray, 2015).

$\mathrm{Bu}$ çalışmada, Çanakkale ilinde tarımsal kalkınma kooperatiflerine ortak olan çiftçilerin kooperatifçilik eğitimi ile ilgili istekleri ve bu isteklerinde etkili olan faktörlerin analizi yapılmıştır.

Buradan hareket ile başarılı kooperatifçilik için kooperatifçilik bilincinin eksiksiz olması gerektiği ortaya çıkmaktadır.

\section{Materyal ve Yöntem}

Araştırmanın ana materyalini Çanakkale ilinde tarımsal kalkınma kooperatiflerine ortak olan çiftçilerle yüz yüze görüşmeler sonucu doldurulan soru formlarından elde edilen birincil nitelikli veriler oluşturmuştur.

Araştırmada birincil ve ikincil nitelikteki verilerden yararlanılmış olup, anket sonucu elde edilen veriler, 
birincil nitelikli verileri oluşturmaktadır.

Araştırmanın ikincil nitelikli verilerini ise Ticaret Bakanlığı başta olmak üzere diğer ulusal ve uluslararası kurumların istatistik ve yayınlarından elde edilen veriler, diğer araştırmacılar tarafindan yapılmış olan araştırma sonuçları, derleme, inceleme ve tezlerden elde edilen veriler oluşturmaktadır.

Çanakkale ili Bozcaada ve Gökçeada dahil on iki ilçeden oluşan bir ildir. Örnek hacmi belirlenirken tüm ilçelerde bulunan tarımsal kalkınma kooperatifleri arasından en fazla ortağı olan tarımsal kalkınma kooperatifi her ilçe için gayeli olarak seçilmiştir.

Gayeli olarak seçilen bu kooperatiflerin ortak sayıları araştırmanın popülasyonunu oluşturmuştur (3674 ortak). Söz konusu popülasyonun örnek hacmi aşağıdaki formüle göre belirlenmiştir (Miran, 2010).

$$
\mathrm{n}=\frac{\mathrm{Np}(1-\mathrm{p})}{(\mathrm{N}-1) \operatorname{var}^{2} \mathrm{px}+\mathrm{p}(1-\mathrm{p})}
$$

$\mathrm{n}=$ Örneğe çıkan kooperatif ortak sayısı

$\mathrm{N}=$ Ana kitle büyüklüğü

$\mathrm{p}=$ Ana kitle oran

$\operatorname{var}^{2} \mathrm{px}=$ Ana kitle oranının varyansı

Araştırmada \% 10 hata payı ve \% 95 güven aralığı ile çalışılmış ve 93 kooperatif ortağı ile anket çalışması yapılmıştır. Belirlenin örnek hacmi seçilen kooperatifler arasında oransal olarak dağıtılmıştır.

Lojistik regresyon; cevap değişkenin kategorik olarak, ikili, üçlü ve çoklu kategorilerde gözlendiği durumlarda açılayıcı değişkenlerle sebep-sonuç iliş̧kisini belirlemede yararlanılan bir yöntemdir. Açılayıc1 değişkenlere göre cevap değişkeninin beklenen değerlerinin olasıllık olarak elde edildiği sınıflama ve atama işlemi yapmaya yardımcı olan bir regresyon yöntemidir. LR cevap değişkenin (Y) kategorik olarak, ikili (binary, dichotomous) ve çoklu (multinominal) kategorilerde gözlendiği durumlarda açılayıcı değiş̧kenlerle (xi, i = 1,2,..,k) sebep-sonuç ilişkisini belirlemede yararlanılan bir yöntemdir (Özdamar, 2013).

\section{Araştırma Bulguları}

Araştırmanın bu bölümünde genel bulgular, kooperatif ortaklarına ait tarım işletmelerinin genel yapısal özelliklerini ve ortakların kooperatif eğitimi talebi üzerine elde edilen bulgular sunulmuştur.

\subsection{Genel bulgular}

Çalışma kapsamında görüşülen ortakların yaş seviyeleri ortalama 49 yil olarak bulunmuştur. Ortakların \% 52.69'unun yaş seviyesi ortalamanın altında, \% 47.31'inin yaş seviyesi ortalamanın üzerindedir. Ortaklarının çiftçilik deneyimi en az 1 yıl en fazla 69 y1l olup ortalama 28 yil olarak tespit edilmiştir. Ortaklarının eğitim seviyeleri ele alındığında
\% 1.1'inin okuma yazma bilmeyen, \% 78.5'inin ilköğretim mezunu, \% 14'ünün lise mezunu ve \% 6.5'inin üniversite mezunu olduğu görülmüştür. Ortakların kooperatif genel kurul toplantılarına düzenli olarak katılma durumları araştırılmış̧ır. Buna göre ortakların \% 77.4'ü kooperatif genel kuruluna düzenli katılmaktadır. Ortakların anket çalışmasının düzenlendiği zaman diliminde ya da daha önce kooperatif yönetiminde görev alıp almadıkları ele alınmıştır. Buna göre ortakların \% 35.48'inin kooperatif yöneticiliği ile ilgili deneyimi bulunmaktadır. Tarımsal bilgiye ulaşmada tarımsal toplantılara katılım önemli olup ortakların \% 31'i son bir yıl içerisinde herhangi bir tarımsal toplantıya katılmıştır. Tarımsal bilgiye ulaşmada internet kullanımı kooperatifçilik bilinci üzerinde olumlu yönde etkili olup (Everest, 2015) çalışmada görüşülen ortakların \% 44.1'inin tarımsal bilgiye ulaşmada internetten faydalandıkları görülmüştür. Tarımsal fuarlara düzenli olarak katılım da tarımsal bilgiye katkı sağlayan yayım çalışmalarından olup, çalışma kapsamında görüşülen çiftçilerin \% 62.4'ünün tarım fuarlarına düzenli olarak katıldığı saptanmıştır.

\subsection{Tarımsal yapı bulguları}

Çalışma kapsamında ortakların tarımsal faaliyetlerinde kullandıkları arazilere ait veriler şu şekildedir; mülk arazi, suluda ortalama 38.22 da ve 2.7 parça, kıraçta ortalama 32.62 da ve 4 parçadır. Kira olarak işlenen arazi suluda ortalama 25.22 da ve 3.7 parça, kıraçta ortalama 30 da ve 3.1 parçadır. Ortakçılık ile işlenen arazi suluda ortalama 11.4 da ve 2.6 parça, kıraçta 42.67 da ve 3.3 parçadır.

Ortakların bir yıllık tarımsal faaliyetleri sonucunda elde ettikleri gelir araştırılmıştır. Buna göre ortakların \% 41.49'unun bir yıllık tarımsal geliri 10.000 TL'nin altındadır. Bunu sirasiyla \%35.48 ile 10.001-20.000 TL gelir aralığı, \% 16.23 ile 20.001-50.000 TL gelir aralığ ve \% 6.45 ile 50.001-100.000 TL gelir aralığ1 takip etmektedir. Ayrıca ortakların \% 52.7'sinin emeklilik, kira gibi tarım dışı geliri bulunmaktadır.

\subsection{Kooperatifçilik eğitimi talebi}

Çalı̧̧ma kapsamında kooperatif ortaklarının bu zamana kadar kooperatifçilikle ilgili herhangi bir eğitim alıp almadıklarının araştırılmıştır. Buna göre ortakların sadece \% 6.5'i kooperatifçilik konusunda bir eğitim almıştır. Eğitim alan 6 kişinin katıldığı eğitimlerin 2 tanesi üst birlik, 2 tanesini Milli Eğitim Bakanlığ 1 ve 2 tanesini Tarım ve Orman Bakanlığı düzenlemiştir.

Araştırma kapsamında kooperatif ortaklarına kooperatifçilik konusunda eğitim almayı isteyip istemedikleri de ele alınmıştır. Buna göre kooperatif ortaklarının \% 61.3’ü kooperatif̧̧iliği daha iyi öğrenmek istemektedirler ve kooperatifçilik konusunda eğitim almak istemektedirler.

Kooperatif eğitimi almak istemeyenlerin ise 
\% 19.4'ü böyle bir eğitime gerek olmadığını düşünmekte, \% 16.7'si eğitimle uğraşmak istememekte, $\%$ 50'si yaşlı olduğu için ve \% 13.9'u ise zamanı olmadığı için kooperatifçilik eğitimi almak istememektedir.

Araştırmada kooperatifçilik eğitimi almak isteyenlere olası kooperatif̧̧ilik eğitimi konuları sunulmuştur. Buna göre ortakların konularına göre kooperatif eğitimi alma taleplerini karşılaştırma yapmak ve önem derecelerini belirlemek amaciyla unsurlara ağırlık verilmiş, ağırlıklar unsurların yüzdeleri ile çarpılarak skorlar belirlenmiştir. Elde edilen skorlar sıralanarak kooperatifçilik eğitimi konuları arasında karşılaştırma yapılmış ve ortakların hangi konularda eğitim almak istedikleri sıralanmıştır.

Buna göre ortaklar en çok başarılı kooperatif örnekleri hakkında bilgi almak ve bu kooperatifleri yerlerinde ziyaret etmek istemektedirler.

Ortaklar ikinci olarak pazarlama konusunda eğitim almak istemektedirler. Ortaklar tarafindan üretilen ürünlerin işlenmesi, markalaşması ve satışı gibi konular kooperatif ortaklarının ilgisini en çok çeken ikinci konudur.

Üçüncü olarak kooperatif ortaklarının kooperatifleri için proje hazırlama konusunda eğitim almak istedikleri bulunmuştur. Ortakların kooperatifçilikle ilgili eğitim almak istedikleri diğer konular ise sirasiyla "kooperatiflerde denetim", "kooperatif yönetimi", "kooperatif ilkeleri" ve "kooperatifçiliğin tarihçesi" şeklinde devam etmektedir (Çizelge 1).

Çalışmada kooperatif ortaklarının kooperatifçilik konusunda eğitim almak istekleri üzerinde etkili olan faktörler Lojistik Regresyon (LR) ile analiz edilmiştir (Çizelge 2).

Modellerin açıklamasında kullanılan açıklayıcı değişkenler yaş (yıl), eğitim durumu (1: okuma yazma bilmeyen, 2: ilkokul, 3:lise, 4:üniversite), çiftçilik deneyimi (y1l), tarımsal toplantılara katılma durumu (1:katılan, 2:katılmayan), internet kullanma (1:kullanan, 2:kullanmayan), tarımdan elde edilen yıllık gelir (1: $<10.000$ TL, 2:10.001-20.000 TL, 3:20.001-50.000, 4:50.001-100.000, 5>100.000), tarım dış1 gelir varlığı (1:var, 2:yok), son yapilan genel kurul toplantisina katılma durumu (1:katılan, 2:katılmayan), kooperatifte geçmişte ya da güncel yöneticilik yapma durumu (1:deneyimi olan, 2:deneyimi olmayan), tarımsal fuarları takip etme durumu (1:takip eden, 2:takip etmeyen) olarak belirlenmiştir.

Çizelge 1. Talep Edilen Kooperatif̧̧ilik Eğitimi Konuları

\begin{tabular}{|c|c|c|c|c|c|c|c|}
\hline Eğitim Konusu & 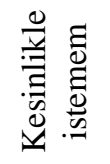 & 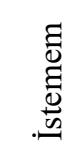 & 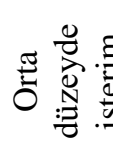 & 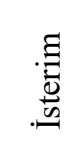 & 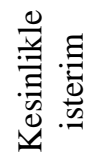 & $\begin{array}{l}\overline{0} \\
\frac{y}{n}\end{array}$ & 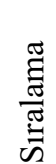 \\
\hline & 1 & 2 & 3 & 4 & 5 & & \\
\hline Başarılı kooperatif örneklerini inceleme & 3.2 & 12.9 & 1.1 & 35.5 & 29.0 & 319.5 & 1 \\
\hline Pazarlama & 5.4 & 16.1 & 0.0 & 29.0 & 31.2 & 309.67 & 2 \\
\hline Kooperatiflerde proje hazırlama imkânları & 3.2 & 18.3 & 1.1 & 35.5 & 23.7 & 303.22 & 3 \\
\hline Kooperatiflerde denetim & 4.3 & 21.5 & 1.1 & 30.1 & 24.7 & 294.62 & 4 \\
\hline Kooperatif yönetimi & 5.4 & 23.7 & 1.1 & 25.8 & 25.8 & 288.17 & 5 \\
\hline Kooperatif ilkeleri & 5.4 & 23.7 & 3.2 & 30.1 & 19.4 & 279.56 & 6 \\
\hline Kooperatifçiliğin tarihçesi & 7.5 & 31.2 & 1.1 & 28.0 & 14.0 & 254.83 & 7 \\
\hline
\end{tabular}

Çizelge 2. Kooperatifçilik Konusunda Eğitim Almak İstemede Etkili Olan Faktörler

\begin{tabular}{|c|c|c|c|c|c|}
\hline Değişkenler & Katsay 1 & Std. Hata & p-Değeri & & Eğim \\
\hline Sabit & 4.64497 & 3.07729 & 0.13119 & & \\
\hline Yaş & -0.077791 & 0.0379704 & 0.04049 & ** & -0.0194469 \\
\hline Eğitim & 0.259658 & 0.496207 & 0.60078 & & 0.0649115 \\
\hline Çiftçilik deneyimi & 0.0470519 & 0.0297826 & 0.11414 & & 0.0117624 \\
\hline Tarımsal toplantılara katılma & -0.80587 & 0.559802 & 0.14999 & & -0.201458 \\
\hline İnternet kullanma & 1.18688 & 0.686552 & 0.08385 & $*$ & 0.296707 \\
\hline Tarımsal gelir & 0.259823 & 0.272905 & 0.34106 & & 0.0649528 \\
\hline Tarım dışı gelir varlığı & -0.263038 & 0.604158 & 0.66329 & & -0.0657566 \\
\hline Genel kurula katılma & -0.851306 & 0.58115 & 0.14296 & & -0.212817 \\
\hline Yöneticilik deneyimi & -0.736383 & 0.609947 & 0.22732 & & -0.184087 \\
\hline Tarımsal fuarlara katılma & -0.918643 & 0.526751 & 0.08116 & $*$ & -0.22965 \\
\hline
\end{tabular}

Likelihood ratio test: Chi-square $(10)=18.0983 ;(\mathrm{p}=0.0533)$ ***:\%1 önem derecesi, **: \%5 önem derecesi, *:\%10 önem derecesi 
LR modelinin bağımlı değişkeni kooperatifçilik konusunda eğitim alma isteği olup, eğitim almak isteyenler 1, eğitim almak istemeyenler 0 olarak kodlanmıştır.

Likelihood ratio test sonucu, modelin istatistiki olarak geçerli olduğunu göstermektedir $\left(X^{2}: 18.0893\right.$, p:0.0533). Analiz sonucuna göre;

Çiftçilerin yaş seviyeleri ile kooperatifçilik konusunda eğitim almak istemeleri arasında negatif yönlü bir ilişki tespit edilmiştir. Buna göre yaş seviyesinin onar onar artması eğitim alma isteği eğilimini \%19 azaltmaktadır.

İnternet kullanma durumu ile eğitim almak isteme arasındaki ilişki pozitif yönlü bulunmuştur. İnternet kullanmayanlar internet kullananlara göre yaklaşık \%30 daha fazla eğitim alma eğiliminde olan kişilerdir.

Tarımsal fuarlara katılma ile kooperatif eğitimi alma isteği arasındaki ilişki de istatistiki olarak anlamlı bulunmuştur. Buna göre tarımsal fuarlara katılanlar, fuarlara katılmayanlara göre yaklaşı $\% 23$ daha fazla kooperatifçilik eğitimi alma eğilimindedirler.

Çizelge 3. Kooperatif Ortaklarının Kooperatifçilik Eğitimine Yönelik Bilinç Düzeyleri

Kriter

\begin{tabular}{|c|c|c|c|c|c|c|}
\hline 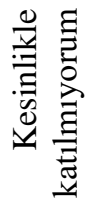 & 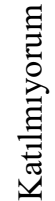 & 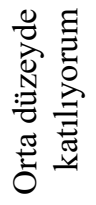 & 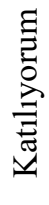 & 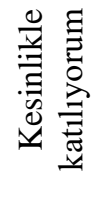 & $\frac{\tilde{o}}{\tilde{v}}$ & 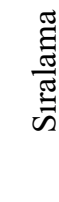 \\
\hline
\end{tabular}

\begin{tabular}{|c|c|c|c|c|c|c|c|}
\hline & 1 & 2 & 3 & 4 & 5 & & \\
\hline $\begin{array}{l}\text { Kooperatif yöneticilerine yöneticilik eğitimi } \\
\text { verilmelidir }\end{array}$ & - & 1.1 & - & 22.6 & 76.3 & 474.1 & 1 \\
\hline $\begin{array}{l}\text { Kooperatiflerde kooperatif eğitimi almış kişiler } \\
\text { istihdam edilmelidir }\end{array}$ & - & 2.2 & - & 28.0 & 69.9 & 465.5 & 2 \\
\hline Kooperatif eğitimi gençlere de verilmelidir & 1.1 & 4.3 & 2.2 & 28.0 & 64.5 & 450.5 & 3 \\
\hline $\begin{array}{l}\text { Televizyon kanallarında kooperatif programları } \\
\text { yapılmalıdır }\end{array}$ & - & 4.3 & 2.2 & 41.9 & 51.6 & 440.8 & 4 \\
\hline $\begin{array}{l}\text { Kooperatif eğitimini kooperatiflerden sorumlu } \\
\text { bakanlıklar düzenlemelidir }\end{array}$ & - & 11.8 & 6.5 & 38.7 & 43.0 & 412.9 & 5 \\
\hline Kooperatif eğitimi kadınlara da verilmelidir & 3.2 & 12.9 & 4.3 & 26.9 & 52.7 & 412.9 & 5 \\
\hline Kooperatif eğitimi çocuklara da verilmelidir & - & 20.4 & 3.2 & 32.3 & 44.1 & 400.0 & 6 \\
\hline Radyolarda kooperatif programı yapılmalıdır & 12.9 & 11.8 & 12.9 & 30.1 & 32.3 & 356.9 & 7 \\
\hline $\begin{array}{l}\text { Kooperatif eğitimini kooperatif üst birlikleri } \\
\text { düzenlemelidir }\end{array}$ & 2.2 & 35.5 & 9.7 & 23.7 & 29.0 & 341.9 & 8 \\
\hline
\end{tabular}

Ortakların kooperatifçilik eğitimi üzerine bilinçlerini ölçmek amacıyla kooperatifçilik eğitimine yönelik temsilen seçilen dokuz alt unsur arasında karşılaştırma yapılmış ve önem dereceleri belirlenerek unsurlara ağırlık verilmiş, ağırlıklar unsurların yüzdeleri ile çarpılarak skorlar belirlenmiştir. Elde edilen skorlar sıralanarak kooperatifçilik eğitimi bilinci üzerine karşılaştırma yapılmıştır. Buna göre ortaklar kooperatifçilik eğitimi dendiğinde ilk olarak "kooperatif yöneticilerine yöneticilik konusunda eğitim"in verilmesi gerektiğini düşünmektedir. Bunu sirasıyla "kooperatiflerde kooperatif eğitimi almış kişiler istihdam edilmesi", "kooperatif eğitiminin gençlere de verilmesi", "televizyon kanallarında kooperatif programlarının yapılması", "kooperatif eğitimini kooperatiflerden sorumlu bakanlıkların düzenlemesi", "kooperatif eğitiminin çocuklara da verilmesi", "radyolarda kooperatif programı yapılması" ve "kooperatif eğitimini kooperatif üst birliklerinin düzenlemesi" ifadeleri takip etmektedir (Çizelge 3).

\section{Sonuç ve Öneriler}

$\mathrm{Bu}$ araştırmada, kooperatif ortaklarının kooperatif̧̧ilik konusunda eğitim taleplerinin ve kooperatif̧̧ilik eğitimlerinden beklentilerinin ortaya konmas1 hedeflenmiştir. Yapılan analizlerle şu sonuçlara ulaşılmıştır:

Kooperatif ortaklarının büyük çoğunluğu kooperatif yönetim kurulu toplantıların katılmaktadır. Yani ortaklar kooperatiflerine sahip çıkmaktadırlar. Oysa ortakların tarımsal toplantılara katılma oranları düşük olup çiftçilere yönelik tarımsal eğitimlerin ya da toplantıların artırılması önerilmektedir.

Ortakların neredeyse tamamı (\% 93$)$ kooperatifçilikle ilgili herhangi bir eğitim almamış olup, önemli bir kısmı kooperatifçilik konusunda eğitim almak istemektedir (\% 61). İlgili bakanlıklar, üst birlikler ve üniversitelerin katılımıyla kooperatifçilik yayım programlarının hazırlanması ve uygulanması önerilmektedir. 
Ortaklara kooperatifçilikle ilgili almak istedikleri eğitimlerin içeriği sorulduğunda en fazla "başarılı kooperatiflerle buluşma" talebinin olduğu bulunmuştur.

Yaş seviyesi azaldıkça kooperatifçilik eğitimi alma isteği artmaktadır. Yani genç çiftçiler kooperatifçilik eğitimlerine karşı daha fazla ilgilidirler. Dolayısıyla etkili eğitim programlarının gerçekleştirilmesinde gönüllülük esasının önemi düşünüldüğünde kırsal alanda verilecek kooperatifçilik eğitimlerine öncelikle genç çiftçilerin katılımının sağlanması önerilmektedir.

Tarımsal bilgiye ulaşmada internet kullanmayanların internet kullananlara göre daha fazla kooperatifçilik eğitimi alma eğiliminde olması kırsal alanda bilgiye ulaşma talebinin olduğunu açıç̧a ortaya koymaktadır. Ayrıca internet kullanımının yaygınlaştııılması önerilmektedir.

Tarımsal fuarlara katılan kişilerin kooperatif eğitimi alma eğiliminde olmaları fuarlara katılmanın önemini ortaya koymaktadır. Kooperatiflere ve diğer çiftçi örgütlerine fuarlara katılımla ilgili yayım çalışmalarını yoğunlaştırmaları önerilmektedir.

\section{Teşekkür}

$\mathrm{Bu}$ araştırmaya 2209/A Program Kodu ile finansal destek sağlayan TÜBİTAK'a ve anket sorularına sabırla yanıt veren kooperatif ortaklarına teşekkür ederiz.

\section{Kaynaklar}

Adrian, J. L., Gren, T., W., 2001. Agricultural Cooperative Managers and the Business Environment. Journal of Agribusiness, Volume. 19, Issue 1 (Spring) 17-33 p. http://purl.umn.edu/14685

Aydoğan, M., Demiryürek, K., Yulafcı, A., 2016. Samsun İli Tarımsal Üretici Örgütleri Arasındaki İşbirliğinin Örgüt Başarısına Etkisi, Anadolu Tarım Bilim. Dergisi, Say1:31, No:2, ISSN: 1308-8750, $\mathrm{s}: 215-222$

Didier, V., B., Henninger, M., C., Akremi, A., E., 2012. The Relationship Between Members' Trust and Participation in the Governance of Cooperatives: The Role of Organizational Commitment. International Food and Agribusiness Management Review Volume 15, Issue 1.

Dinler, Z., 2008. Tarım Ekonomisi. Ekin Kitabevi Yayınları. 6. Basım. Bursa.

Espallardo, M., H., Lario, N., A., Mata's, G. M., 2012. Farmers' Satisfaction and Intention to Continue Membership in Agricultural Marketing Cooperatives: Neoclassical Versus Transaction Cost Considerations. European Review of Agricultural Economics pp. 1-22. doi: 10.1093/erae/jbs024.

Everest, B., 2015. Tarım Kredi Kooperatiflerinde Ortakların Kooperatifçilik İlkelerini Algılamaları Ve Yönetime Katılmalarını Etkileyen Faktörlerin Analizi Üzerine Bir Araştırma: Balıkesir Bölge Birliği Örneği. Ege Üniversitesi Fen Bilimleri
Enstitüsü Tarım Ekonomisi Anabilim Dalı Doktora Tezi.

Everest, B., Tan, S., 2016. A Study on Cooperative Relationship and Social Interaction with Other Disciplines. International Balkan and Near Eastern Social Sciences Conference Series IBANESS Conference Series-Plovdiv/BULGARIA p. 208-213.

Geray, C., 2015. Kooperatif̧̧ilik. Nika Yayınevi. S:42.

Gray, T., Kraenzle, C., A., 1998. Member Participation in Agricultural Cooperatives: A Regression and Scale Analysis, Rural Business-Cooperative Service Research Report 165.

Ticaret Bakanlığı, 2018a. Gümrük ve Ticaret Bakanlığı, Kooperatifçilik Genel Müdürlüğü, http://koop.gtb.gov.tr/kooperatifler-

hakkinda/kooperatif-nedir (Erişim tarihi: 14 Ocak 2019).

Ticaret Bakanlığı, 2018b. Gümrük ve Ticaret Bakanlığı, Kooperatifçilik Genel Müdürlüğü, Türkiye Kooperatifçilik Stratejisi ve Eylem Planı, https://www.gtb.gov.tr/data/51c7eb1d487c8e0a98f1 $5 \mathrm{fgb} /$ türkiye\%20kooperatifçilik\%20stratejisi\%20ve \%20eylem\%20plan1\%20(2012-2016).pdf (Erişim tarihi: 14 Ocak 2019).

Güreşçi, E., Gönç, M., 2017. Türkiye'de Kooperatiflerin Temel Sorunları Ve Çözüm Önerileri Üzerine Düşünceler. Üçüncü Sektör Sosyal Ekonomi, 52 Özel Sayı, s. 219-229.

Hazneci, E., Hazneci, K., Kılıç, B., Ceyhan, V., 2012. Samsun İlinde Kadın Çiftçilerin Kooperatifleşmeye Karşı Tutumları, 10. Ulusal Tarım Ekonomisi Kongresi , s:1003-1008. 5-7 Eylül, Konya.

ICA, 2019. (International Co-operative Alliance) World Cooperative http://www.euricse.eu/wp-content/ uploads/2017/11/WCM_2017web-EN.pdf (Erişim tarihi: 09 Mart 2018).

Karthikeyan, M., 2013. Social Statement Approach to Cooperative Social Performance Assessment: A Case of Lume Adama Farmers Cooperative Union in Ethiopia. 4th EMES International Research Conference on Social Enterprise. EMES-SOCENT Conference Selected Papers, no. LG13-23.

Laursen, C., V., Karantininis, K., Bhuyan, S., 2008. Organizational Characteristics and Member Participationin Agricultural Cooperatives: Evidence from Modern Danish Cooperatives. Paper Submitted To The Seminar: The Role of The Cooperatives in The European Agro-Food System 28th-30th May, Bologna.

Miran, B., 2010. Temel İstatistik. ISBN:975-93088-0-0. s.142.

Mülayim, Z., G., 2010. Kooperatifçilik. Yetkin Yayınları. s. 34.

Oladejo, M., O., 2013. Stakeholders Perception of Cooperative Societies as a Micro-Credit Delivery Channel in the Nigerian Financial Sector Reform Era. IRMBR Journal. Vol. 2 Issue.2. ISSN: 23069007. 457-469 p. 
Özdamar, K., 2013. Paket Programları İle İstatistiksel Veri Analizi. Nisan Kitabevi. S. 551.

Prakash, D., 2003. The Principles of Cooperation, - A Look at The ICA Cooperative Identity Statement. International Cooperative Alliance [World Headquarters], Geneva. Switzerland.

Semerci, A., 2015. Türkiye'de Çiftçi Örgütleri: Tarımsal Amaçlı Kooperatifler Örneği, Tekirdağ Ziraat Fakültesi Dergisi, 12(1):65-73.

Tan, S., Karaönder, İ., 2013. Türkiye'de Tarımsal Örgütlenme Politikalarının ve Mevzuatının İrdelenmesi: Tarımsal Amaçlı Kooperatifler Örneği, ÇOMÜ Ziraat Fakültesi Dergisi, 1 (1): 87-94.

Topuz, B. K., Bozoğlu, M. ve Başer, U. 2017. Güncel Gelişmeler Kapsamında Türkiye'deki Çiftçi Örgütlerine Yönelik Mevzuatın Değerlendirilmesi. Üçüncü Sektör Sosyal Ekonomi, 52 Özel Sayı, s. 140-161.
TRGM, 2018. Tarım Reformu Genel Müdürlüğü, Tarımsal Örgütlenme Tablosu. Tarımsal\%20Örgütlenme\%20Tablosu\%20\%2001.11 .2016\%20.pdf (Erişim tarihi: 14 Mart 2018).

Yercan, M., 2007. Türkiye ve Avrupa Birliğinde Tarımın Örgütlenme Deseni ve Tarımsal Kooperatifler. Tarım Ekonomisi Dergisi, 13(1): 19 29.

Xiang, L., Y., Sumelius, J., 2010. Analysis of the Factors of Farmers' Participation in the Management of Cooperatives in Finland. Journal of Rural Cooperation, 38(2): 134-155. ISSN 0377-7480.

Zakic, N., Vukotic, S., Laketa, M., Laketa, L., 2013. Agricultural Co-Operatives: Researching Members' Perception of Important Issues of Co-Operatives on The Example of Serbia. The Journal of Animal \& Plant Sciences, 23(1): 290-297. ISSN: 1018-7081. 